\title{
THE KING OF TYRE IN EZEKIEL XXVIII.
}

THE prophecy in Ezek. xxviii $1-19$, respecting the king of Tyre, has long been considered one of the most obscure passages in the Old Testament. I do not here refer to the difficulties of detail, considerable as they are, but to the general tenor. The Old Testament contains many prophecies directed against Gentile princes, and Ezekiel himself has a series of prophecies directed against Pharaoh, but nowhere do we find anything at all resembling the language addressed to the king of Tyre. What reason can be assigned for this exceptional treatment? So far as I am aware, the question has never been answered; and if I venture to suggest an explanation of my own I wish to state clearly that it claims to be nothing more than a conjecture.

The section which we are considering is subdivided into two parts-the prophecy in the stricter sense of the word, addressed

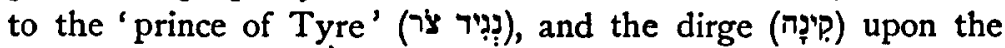

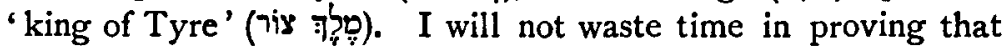
the 'prince' and the 'king' are the same person, though a small number of interpreters have ventured to deny it. It is true that the term נֶֶ, does not happen to occur elsewhere in Ezekiel, but in the historical books it is applied repeatedly to the kings of Israel, and hence its use in this passage presents no difficulty. There is, however, a considerable difference between the earlier verses of the chapter and the dirge which follows, inasmuch as the former deals mainly with the actual situation and pretensions of the king, while the dirge goes back to describe his antecedents, in particular the circumstances which had furnished him with a pretext for claiming to be a god, sitting in the seat of God.

The mere fact that the king of Tyre is accused of claiming to be divine can scarcely astonish us, for we know that many potentates have made this claim, and in Isaiah xiv I3, I4 we find a very similar accusation brought against the king of Babylon. 
It is when we come to the dirge that the real difficulty presents itself. Though Ezekiel does not, of course, admit the king's claim to divinity, he nevertheless seems to place him far above the rest of mankind. He asserts that the king of Tyre was ' in Eden, the garden of God,' ' in the holy mountain of God,' that he 'walked to and fro in the midst of the stones of fire,' that he 'was perfect in his ways from the day that he was created until iniquity was found in him.' It is obvious that the imagery employed here is not simply borrowed from the account of the Garden of Eden and of the fall of man in the early chapters of Genesis, for some of the features which are most prominent in Ezekiel's description-for example, the holy mountain of God and the stones of fire-have no counterpart in Genesis. Nor can we regard these things as mere embellishments arbitrarily inserted by the prophet. The manner in which he introduces them shows that they were already known to his readers, that they formed part of a current religious tradition.

In order to account for this fact most recent interpreters have had recourse to the hypothesis that the two descriptions-that in Ezekiel and that in Genesis-are both reflexes of some ancient myth which was presumably the common property of the Israelites and the neighbouring peoples. In other words, there was a legend about a glorious being, a kind of demigod, who dwelt in a Paradise, on the summit of a lofty mountain, whence he was expelled, as a punishment for some offence against the gods, stripped of his brightness and humbled to the dust. Each of the two Hebrew writers adapted the legend to his purpose, and thus both the resemblances and the differences are explained. So far as I know, the most elaborate statement of this theory is to be found in a treatise by Dr. O. Procksch published last year (1902) under the title Geschichtsbetrachtung und geschichtliche Ueberlieferung bei den vorexilischen Propheten: see pp. 161-164.

The object of my paper is not to controvert the hypothesis adopted by Procksch. But I would venture to point out that, even if he were proved to be in the right, the problem before us would still remain unsolved. The question is not merely, Whence did Ezekiel derive the notion of a demigod expelled from Paradise? but rather, Why is the king of Tyre in particular compared to this mythical being? Is the comparison to be regarded as a mere 
caprice on the part of Ezekiel, or was there some real connexion between the king of Tyre and the legend of a primaeval Paradise?

Let us consider, first of all, what were the circumstances which distinguished the king of Tyre from other potentates. Ezekiel lays stress upon his wisdom, his external splendour and his vast wealth. The magnificence of the Tyrian palace might conceivably have suggested a comparison with the Garden of Eden, but does not account for other features in the description, which imply that in virtue of his office the king of Tyre was invested with a certain religious dignity quite distinct from the material grandeur of ordinary monarchs. His abode is the holy mountain of God, and his offence consists in the fact that he has profaned his

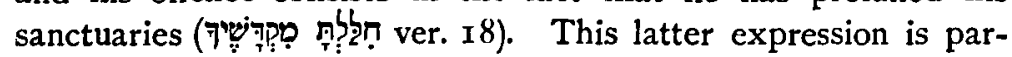
ticularly remarkable, for it seems strange that a Hebrew prophet should regard the profanation of a Gentile sanctuary as a crime of the first magnitude. I venture to think that here we have the clue to the problem. The king is treated by Ezekiel as the occupant of the Tyrian sanctuary, and the Tyrian sanctuary was, for some reason or other, a place of unique importance.

Unfortunately the direct information which we possess with regard to the Tyrian sanctuary is very meagre. But there is one source of indirect information, which, in the present case, must be considered exceptionally valuable. We know from the Book of Kings that Solomon was closely allied with the king of Tyre and that the temple at Jerusalem was built by Tyrians. It is, therefore, reasonable to suppose that the style and decorations of the Solomonian temple were mainly, if not entirely, copied from Tyrian models. Furthermore it is certain that Ezekiel was acquainted with the Solomonian temple and that he, like the compiler of the Book of Kings, was aware of its Tyrian origin. Putting these facts together, we come to the conclusion that the Tyrian sanctuary, as Ezekiel figured it to himself, must have borne a great resemblance to the temple at Jerusalem.

Now if we turn to the description of the Solomonian Temple, we find that its internal decorations were evidently intended to suggest the idea of a garden. The walls and the doors were covered with representations of Cherubim, palm-trees and flowers (I Kings vi 29, 32). The combination of the Cherubim with trees and flowers is in accordance with Gen. iii 24, where the 
Cherubim are described as keeping watch over the Garden of Eden. The vexed question as to the origin and primitive meaning of the Cherubim I do not wish here to discuss. It is enough for our present purpose to observe that they are a feature common to the Garden of Eden and to the Temple. We are thus led to inquire, What is the connexion between the Garden of Eden and the Temple? Is there any reason why a sanctuary should be constructed so as to resemble a garden? The answer, it appears to me, is obvious. As Robertson Smith has so ably shown in his book on the Religion of the Semites (2nd ed., pp. 102 seq.), the oldest sanctuaries of the Semites were natural gardens, that is to say, spots naturally fertile with a perennial supply of water. It must be remembered that in Syria and Palestine such places are far rarer than in our part of the world, and accordingly they could not fail to impress the imagination of the primitive Semitic nomads. To the inhabitants of the steppe, the oasis with its luxuriant vegetation appeared to be, in a literal sense, an abode of the Deity. It was in these exceptionally favoured spots that agriculture was first practised and the oldest settled communities were to be found. Hence followed two results equally important in the history of ancient religion. On the one hand, the idea arose that the garden of the gods, that is, the oasis, was the primitive home of mankind; on the other hand, when men began to build houses for their gods they made the artificial sanctuary after the pattern of the natural sanctuary where their forefathers had worshipped. I do not venture to speculate as to which of these two results came first in order of time, that is to say, whether the legend of the Garden of Eden is older or later than the building of the earliest Semitic temples. In any case it would appear that the two things were closely connected; the legend of the primaeval garden served to explain the decorations of the sanctuary, and the sanctuary, in its turn, seemed to an uncritical age a standing witness to the truth of the legend.

If, therefore, we have reason to believe that the sanctuary at Jerusalem was a Tyrian importation, it is natural to infer that the legend of the Garden of Eden, in some form or other, was introduced among the Israelites from the same quarter, as an interpretation of the symbolic figures wherewith the. sanctuary 
was adorned. And if the Solomonian Temple was held to be a representation of the Garden of Eden, it is evident that the Tyrian Temple, the prototype of the Solomonian, had an even greater claim to be so regarded. This, it appears to me, is the central idea in Ezekiel's dirge upon the king of Tyre, and it enables us to explain a number of details which would otherwise be unintelligible.

In the first place, the king of Tyre is said to have been in 'the holy mountain of God ' (ver. I4), and he is to be cast as profane 'out of the mountain of God ' (ver. 16). These expressions can scarcely apply to Tyre as a whole, for Tyre was built partly on a strip of coast, partly on two small islands neither of which could properly be described as a mountain. On the other hand, the phrase 'holy mountain' is familiar to us from the Prophets and the Psalms as a designation of the sanctuary of Jerusalem. In most places, the local sanctuary seems to have stood on an eminence overlooking the city (Robertson Smith, Religion of the Semites, and ed., p. 172). This was the case at Jerusalem, and was probably the case at Tyre also, for according to Renan, who carefully investigated the site, the great temple of Melkart at Tyre stood on the highest part of the larger island. Hence the conventional phrase 'holy mountain' might be applied to the sanctuary, though it could not be applied to the city generally. With regard to the 'stones of fire,' it is worth while to notice that, according to Herodotus ii 44, the temple at Tyre contained, in addition to many other rich decorations, a column of emerald which shone by night.

Another point, to which, I think, more importance must be attached, is the list of precious stones worn by the king. In the Massoretic text nine stones are mentioned, the Pĕshițta has eight, and the Septuagint twelve. But these variations do not affect the essential fact-which has often been noticed but never explained-namely, that all the stones here mentioned by Ezekiel reappear in the description of the high priest's breastplate in Exod. xxviii I 7 seq., xxxix ro seq. Now if the Tyrian sanctuary was the prototype of the Solomonian, as I have endeavoured to prove, the resemblance between the garb of the Tyrian king and the garb of the Israelite high priest is particularly significant. The list ceases to be an idle enumera- 
tion, as it must otherwise appear; it is inserted by Ezekiel with a distinct purpose, that of emphasising the status of the king as minister of the sanctuary.

I now come to the most difficult part of the subject, namely, the allusions to the Cherub in this chapter. It is well known that according to the Hebrew text, as vocalised by the Massoretes, the king of Tyre is himself a Cherub (vv. 14, 16), while in the Septuagint the king and the Cherub are treated as distinct. Almost all recent interpreters here follow the Septuagint-rightly, as it seems to me. But unfortunately the Septuagint does not enable us to construct an altogether satisfactory text. On the

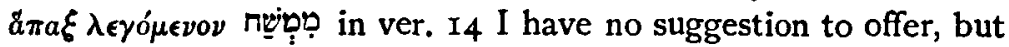
I venture to defend (against Cornill and Bertholet) the genuineness of הoth in ver. 14 and ver. 16 , although the Septuagint omits it. This word is elsewhere applied to the Cherubim in the inner sanctuary, stretching out their wings over the ark (1 Kings viii 7, I Chron. xxviii I 8: cf. Exod. xxv 20, xxxvii 9), and hence, if my interpretation be correct, it is quite appropriate here. It may of course be urged that an inanimate object like the Cherub of the sanctuary could not be said to destroy or drive out the Tyrian king (v. 16). But when we are dealing with a highly rhetorical passage this objection does not seem to me valid. The functions ascribed to the living Cherub in Paradise may, by a very natural figure of speech, be ascribed also to the symbolical Cherub in the Tyrian Temple.

A. A. Bevan. 